\title{
En analyse av språket i Anna Hansdatter Tormods brev fra perioden 1714-1722
}

\author{
Av Agnete Nesse
}

\begin{abstract}
Denne artikkelen er et fors $\varnothing k$ på å utforske mulighetene for å utvikle ny innsikt i hvordan det var for norske skrivere i dansketiden å tilegne seg skriftspråket. Metoden er å bruke tilnærminger til skriftspråklig variasjon brukt innenfor forskning på begynneropplæring på et historisk materiale. Tekstene som blir utsatt for analyse i denne artikkelen, er brev skrevet av en voksen dame på begynnelsen av 1700-tallet. Disse brevene har, selv hvis en sammenligner med brev skrevet av andre skrivere i samme tid, mye variasjon og mange ortografiske særegenheter. Slike uvanlige skrivemåter har i språkhistorisk forskning tradisjonelt blitt rubrisert som enten interessante norvagismer - altså norske dialekttrekk i tekster skrevet på det dansknorske fellesspråket - eller som uinteressant feilskriving uten språkhistorisk verdi. Det er min påstand at også andre trekk enn det som kan rubriseres som dialekttrekk, har en plass i norsk språkhistorie.
\end{abstract}

\section{Innledning}

Det vært lang tradisjon i Norge for å reservere interessen for dansketidens skriftspråk for det som kan klassifiseres som ikke-danske språktrekk i tekster skrevet i Norge. Typiske eksempler på språktrekk som har vært pekt på som norskheter, er bruk av diftong der dansk har monoftong (norsk stein mot dansk sten), bruk av $p, t, k$ der dansk skrift har $b, d, g^{1}$ og bruk av $g$ i ord der dansk skrift har $v$ (norsk hage mot dansk have).

1. Det er et poeng her at det er dansk skrift og ikke nødvendigvis dansk tale som har $b$, $d, g$. I utgangspunktet kunne en si at skriftens $b, d, g$ representerte både norsk $p, t, k$ og de forskjellige danske konsonantene som representeres i skrift av $b, d, g$. Men i den norske Ausbau-prosessen ble det et poeng å fremstille $b, d, g$ som spesifikt danske. 
Den som for alvor igangsatte forskningen på norskheter i tekster av norske skrivere i dansketiden, var Didrik Arup Seip (1884-1963). Etter hans verk Norskhet i sproget hos Wergeland og hans samtid (1914) kom der en rekke studier som var gjort over samme lest. Av studier som berører språket på 1600- og 1700-tallet, kan nevnes Seips eget arbeid om norskheter hos Holberg (1954), Alfred Jakobsens studier av norskheter hos Petter Dass (1952) og Egil Pettersens studier av norskheter hos Dorothe Engelbretsdatter (1957). Arbeidene holder gjennomgående høy kvalitet, og er resultat av grundige studier av store mengder data. (For en mer utførlig liste over norskheter og forskningen på dem, se Nesse 2011: 38 og Nesse 2013: 110-112). Det er likevel vanskelig å bruke disse arbeidene som grunnlag for en helhetlig analyse av skriftspråket i Norge i denne perioden. Forskningsspørsmålene de tidligere forskerne stilte, er hva som er norsk i det de norske skrev. Min påstand er at spørsmålet like gjerne bør være hvordan de norske brukte de språklige ressursene de hadde tilgang til for å skrive så godt de kunne. En slik tilnærming finner en også i arbeid med flerspråklighet, for eksempel i teorier om transspråking (se for eksempel García \& Wei 2013).

Mitt $\emptyset$ nske er å få frem at det felles, dansknorske skriftspråket må ha sin selvfølgelige plass som forskningsobjekt for norske språkhistorikere. I løpet av dansketiden $\varnothing$ kte lese- og skriveferdigheten i den norske befolkningen kraftig, og nye grupper tok del i skriftkulturen (Fet 1995, 2005; Hagland m.fl. 2018: 39-50). I løpet av denne perioden var det også at ideen om standardisering av skriftspråket tok form (Vikør 2018). Vi kan følge en forandring fra at fellesspråket var unormert og med stor aksept for heterogen ortografi, også blant skrivere med høy utdannelse, til at skriftspråket ble normert, noe som førte til at avvik i større grad ble sett på som problematisk. Standardisering medførte at forbindelsen mellom skriftspråket og talemålet i København ble tettere, samtidig som standardisering førte til $\varnothing \mathrm{kt}$ oppmerksomhet rundt rettskrivning. Utover på 180o-tallet ble denne oppmerksomheten ikke bare knyttet til at folk skulle skrive på samme måte. Grammatikere, både i Danmark og Norge, ble opptatt av å forandre rettskrivningen for å få den mer systematisk. Men mens vi vet mye om hvordan disse grammatikerne tenkte (se for eksempel Nygård 1945 og Jacobsen 2010), vet vi ikke så mye om hvordan og i hvor stor grad de skrivende tok til seg nye måter å skrive på.

Denne artikkelen er et fors $\varnothing \mathrm{k}$ på å bøte på dette. Valget om å se til begynneropplæring for analysemetoder fremstår kanskje ikke som in- 
tuitivt selvfølgelig, men kan likevel vise seg å være egnet for en nødvendig fornyelse. Analyse av begynnertekster skrevet av unge skrivere, slik metoden er utviklet blant annet av Ulf Teleman (1979), Geirr Wiggen (1992) og Turid Fossby Elsness (2002), innebærer at tekster analyseres på flere nivå, og at feiltyper forklares ikke bare ut fra forholdet mellom tale og skrift, men også ut fra påviste vanskeligheter i det å tilegne seg skrift. Hos Wiggen \& Elbro (1994) diskuterer en rekke forskere hvordan en kan kategorisere feiltyper, hvordan de kan forstås og hvordan de kan forklares. Både i eldre tekst og i barns tekster er det for eksempel relativt vanlig å finne utelatelse av $n$ eller $m$ (se Schulte 2018: 69, 98 for eksempel fra runeskrift, og Wiggen 1992: 233 for eksempel fra barns skrift). I eldre tekst vil en ofte henvise til tradisjon og konvensjon, for eksempel at nasalstrek kunne brukes for å markere utelatelse av nasal, men også andre bokstaver (Haugen 2004: 207). I barnetekster kan en ikke vise til tradisjon, siden begynnerskrivere ikke kjenner til en slik tradisjon. Derfor vil en heller se på hvilke språklige omgivelser den utelatte nasalen har, noe som fører til en mer generell, fonetisk analyse. Wiggen diskuterer blant annet om utelatelse av nasaler kan skyldes at barnet tolker det slik at nasaliteten er knyttet til vokalen foran, som derfor får representere den utelatte nasalen i skrift (Wiggen 1992: 233).

Et mye brukt skille i analyse av elevtekster er skillet mellom kunnskapsfeil og utføringsfeil. En gjennomgående skrivning av dumt som < domt> betyr at eleven ikke har automatisert bruken av bokstavene $u$ og $o$ for å gjengi talens /u/-lyd. Dette vil kalles en kunnskapsfeil. Hvis eleven derimot har lært seg at mange ord har $\langle\mathrm{h}\rangle \mathrm{i}$ begynnelsen eller $<\mathrm{d}>$ i slutten av ordet uten at disse høres, kan et ord som jordber skrives $<$ hjorbærd>. Dette er en såkalt utføringsfeil som tyder på at eleven har fătt med seg at det skal være en stum bokstav i dette ordet, men hen er ikke sikker på hvilken bokstav som skal brukes, og hvor i ordet det stumme elementet dukker opp.

En grunn til å diskutere variasjon i rettskrivningen i eldre tekster er at den utbredte ideen om at variasjon oftest skyldes talemålet til skriveren (se for eksempel de omtalte norskhetsstudiene av Seip, Jakobsen og Pettersen), bør problematiseres. I utgangspunktet kan en gjerne si at all rettskrivningsvariasjon er talebasert, men dette betyr ikke nødvendigvis at det er dialekten til skriveren som slår gjennom. Og om den er det, er det ikke alltid slik at tolkningen er entydig: En skrivemåte som <jolbær> kan være talebasert, siden mange norske språkbrukere har tjukk 1 av his- 
torisk $r ð$, og uttaler jordbær som /ju:rbær/. Skrivemåten <jolbær> kan også oppstå som talebasert hos barn som ennå ikke har lært å uttale $r$, og som erstatter lyden med $l$. L-uttale av /r/ opptrer sjelden i dialekter med skarre-r, men er hyppig i dialekter med rulle-r. Skrivemåten reflekterer enten at skriveren har tjukk $1 \mathrm{i}$ talemålet, eller at vedkommende er et barn som ennå ikke har lært å uttale $\mathrm{r}$. I et slikt tenkt tilfelle ville en kunne tolke dette som dialektpåvirket skrift. Så mens vi ikke kan lære så mye om dialekten hvis en skriver velger $<$ hjorbærd $>$, så kan $<$ jolbær $>$ gi noen flere holdepunkt.

De viktigste betenkelighetene med å koble språkhistorie og elevtekstanalyse på den måten jeg gjør her, er for det første at det teoretiske rammeverket som elevtekstanalysene er bygget over, er knyttet til barn og til deres kognitive forutsetninger for å lære skriftspråk. Disse er ikke de samme som hos voksne. Når vi bruker slike teorier på tekster skrevet av voksne, vil det derfor kunne oppstå feiltolkninger. Det andre er at mens vi i dag har fastsatte rammer for hva som er korrekt rettskrivning, eksisterte ikke eksplisitte normer på begynnelsen av 1700-tallet. Men i og med at det går an å lese hva folk skrev, har der vært internaliserte normer som anga noen rammer for hvordan ord kunne skrives. Disse var tydeligere hos trente enn hos utrente skrivere.

En tredje betenkelighet er at vi står i fare for å overføre vårt eget skille mellom riktig og gal rettskrivning. Samtidig er det viktig å bli kjent med den variasjonen som fantes i den tidens skriftspråk, både for å få kunnskap om tidens praksis, og for å lære noe om hvordan skriftspråket endres - også som følge av mindre trente skriveres praksis. Som uttrykk for den internaliserte normen som i hvert fall trente skrivere har fulgt, kan vi se til historiske ordbøker. Rettskrivningsvariantene som står i de historiske ordb $\varnothing$ kene, er ikke former som en instans - offentlig eller privat - har satt godkjentstempel på, det er en presentasjon av former belagt $\mathrm{i}$ skrift, og oftest er flere varianter presentert. Når det gjelder kunnskap om vanlige skrivemåter av ord på 160o- og 1700-tallet, er det en rekke ordb $\varnothing$ ker som kan være til nytte. Det Danske Sprog- og Litteraturselskab har samlet fire historiske ordbøker på nett. De er knyttet sammen slik at hvis en søker i en av dem og ordet ikke finnes der, så henvises man automatisk til en av de andre ordb $\varnothing$ kene hvis ordet finnes der. Siden disse ordbøkene har vært viktige for analysearbeidet, presenteres de kort her: 
Kalkars ordbog dekker perioden 1300-1700. Denne er viktig for de eldre formene som fremdeles var i bruk på begynnelsen av 1700-tallet. Eldre skriftformer kunne også være inspirert av lesning i eldre bøker.

Moths ordbog dekker perioden like f $\varnothing \mathrm{r}$ og like etter år 1700.

Holbergordbog er særlig nyttig når en arbeider med tekster skrevet i Norge, i og med at en del ord hos Holberg har semantisk innhold som ikke nevnes i de andre ordb $\varnothing$ kene. Nettopp ved å sammenligne Holbergordbog med de andre tre fortløpende, ser en at Holberg var noe mer preget av sin vestnorske oppvekst enn han selv mente. Holbergordbog dekker perioden $1700-1750$.

Ordbog over det danske Sprog dekker perioden 1700-1950. Denne har en del felles med Holbergordbog, fordi svært mange av de sitatene som brukes i ODS er sitat fra Holbergs tekster.

I denne artikkelen skal vi videre helt kort presentere brevsjangeren og forskningen på den. Deretter presenteres Annas miljø, og utgivelsen som de språklige analysene bygger på. Hoveddelen av artikkelen er de språklige analysene av Annas brev. Rettskrivningsnivået diskuteres først og grundigst, før en kortere del om syntaks og ordforråd, med særlig vekt på tiltaleformer avslutter artikkelen.

\section{Brevforskning}

Vi har en lang tradisjon i Norge for å forske på språket i brev, men dette har primært vært knyttet til høy- og senmiddelalderen. Det store tekstmaterialet i Diplomatarium Norvegicum, som inneholder tekster frem til andre halvdel av 1500-tallet, består i stor grad av brev, og mye er skrevet om disse. Endre Mørck har foretatt analyser av brevmaterialet fra den mellomnorske perioden i flere publikasjoner. Av nyere verk kan nevnes Mørck (2011), som tar for seg leddstillingen i mellomnorske helsetninger, og kapittelet om mellomnorsk («Seinmellomalderen») i bind IV av Norsk språkhistorie fra 2018. Fra perioden etter 1600 er det mindre å finne av denne typen studier. Både Pettersens analyser av skriftspråket til Dorothe Engelbretsdatter (1957) og Jacobsens analyser av skriftspråket til Petter Dass (1952-1953), inneholder riktignok henvisninger til språktrekk brukt i rimbrev, men som nevnt er den overordnete problemstillingen $\mathrm{i}$ disse arbeidene forekomster av norskheter, ikke helhetlig analyse av brevspråk. 
Mer spesifikt innrettet mot brev er Wiggen (2004), som tar for seg språk og språkbruk i Conradine Dunkers brev fra årtiene rundt 180o. I disse tekstene har Wiggen kartlagt metaspråklige kommentarer og bruk av andre språk enn dansknorsk. Han noterer også variasjon i rettskrivningen til Dunker, uten å gjøre en systematisk analyse. Karakteristikken av Dunkers ortografi er slik:

Den eksemplifiserer [...] godt den intraindividuelle inkonsistensen som Gregersen (1984: 169f.; jf. Wiggen u.u.) har funnet karakteriserer de danskskrivendes ortografi generelt i første del av 1800 -tallet, d.e. Conradine Dunkers samtidige. (Wiggen 2004: 65).

Wiggen mener også, på grunnlag av studier av miljøet rundt Dunker, at ikke alle i det $\varnothing$ vre samfunnssjiktet kunne lese og skrive på denne tiden. Både intraindividuell variasjon og manglende lese- og skrivekyndighet er relevant kunnskap for brevene som skal analyseres i denne artikkelen.

Det har vært noe mer interesse for språkvitenskapelig brevforskning knyttet til moderne tid hos dem som forsker på andre europeiske språk. To tilnærminger kan nevnes her, eksemplifisert ved Thomas Sokoll (2006) og Stephan Elspaß (2015). Sokoll, som skriver om engelsk språkhistorie, ser særlig på de retoriske figurene i såkalte pauper letters, altså brev fra fattige til myndighetene, der de ber om underst $\varnothing$ ttelse. Han konkluderer med at en må se de retoriske figurene i disse brevene som inspirert både av den stilistikken som preget skriftkulturen, og av muntlige mønstre. Ut fra de eksempelbrevene han gjengir i artikkelen, er det lett å se at dette også gjelder for ortografien. For Elspaß, som arbeider med tysk språkhistorie, er det viktig å undersøke om ikke privatbrev kan brukes til å nyskrive tysk språkhistorie "nedenfra», altså at slike data kan presentere et alternativ til den standardfokuserte språkhistorien det har vært vanlig å legge mest vekt på i de tyskspråklige språksamfunnene. I arbeidet med folkelige tekster opererer han, i tråd med Koch og Oesterreicher (1985), med en todeling i language of immediacy (conceptually oral) og language of distance (conceptually literate) (Elspa 3 2015: 4). Vi ser altså at også Elspa $\beta$, som Sokoll, er opptatt av skriftkyndighetens doble kilder: De skrivende er både påvirket av stilistiske mønstre knyttet til spesifikke skriftlige sjangre, og de er påvirket av sin egen muntlighets umiddelbarhet. Begge disse faktorene kjenner vi igjen i Annas brev. 
Elspa $\beta$ går gjennom flere grammatiske kategorier, og viser at trekk som har blitt sett på som feil og avvik, var svært vanlige i den skriftspråklige praksisen blant vanlige folk på 180o-tallet. For eksempel har det vært hevdet at det å bruke preposisjonen wegen med dativ i stedet for med genitiv er en moderne utvikling, mens Elspa $\beta$ sitt datamateriale viser at wegen + dativ var den vanligste varianten $\mathrm{i}$ tekster skrevet av vanlige folk på 180o-tallet. Han konkluderer med at en ny, tysk språkhistorie bør legge vekt på å forklare hvorfor rene skriftspråklige varianter - som wegen med genitiv - i så stor grad har blitt befestet som det korrekte, både i skrift og i tale, i stedet for flertallets former (Elspaß 2015: 18).

\section{Anna Hansdatter og det miljøet hun levde $\mathbf{i}^{2}$}

Datamaterialet for denne artikkelen er tolv brev skrevet av en kvinne som het Anna Hansdatter eller Anna Hansdatter Tormods, som er det hun skriver under brevene med. Grunnen til at Anna Hansdatters brev i det hele tatt er bevart, er ektemannen hennes. Anna ble ifølge Titlestads artikkel om Torfæus i Norsk biografisk leksikon født ca. 1660, som datter av rådmann i Stavanger Hans Pedersen Gammel og hans andre kone Marie Clausdatter (Titlestad 2009) ${ }^{3}$. Som nevnt fant Wiggen i sine studier at ikke alle i den norske overklassen rundt 1800 kunne lese og skrive. Men Hans Pedersen Gammel var også kjøpmann (Kielland 1935: 3637), og ut fra det vi vet fra andre kjøpmannsmiljø på den tiden (Nesse 2017: 168-169), er det ikke urimelig å anta at lese- og skrivekunsten ble sett på som viktig i familien, og at Anna fikk lære å lese og skrive som barn.

I 1709, da Anna Hansdatter Gammel var 49 år gammel, giftet hun seg med den 73 år gamle enkemannen Tormod Torfæus, ${ }^{4}$ som døde ti år se-

2. I omtalen av personene har jeg vært usikker på om jeg skulle bruke fornavn, etternavn eller initialer, og om jeg, når det gjelder islendingene, skulle bruke islandske eller norskdanske versjoner av navnene, i og med at alle var i bruk. For enkelthets skyld har jeg valgt å kun bruke fornavn, og å holde meg til norskdansk versjon, altså Anna, Tormod og Arne.

3. I Stavangers borgerbok (Kielland 1935: 36-37) er navnene skrevet Hans Pettersen Gammel og Maren Clausdatter Koch.

4. Kålund presenterer flere former av navnet: Dansk versjon Tormod Torvason, islandsk Pormóður Torfason, latin Torfæus. Det siste navnet brukte han som forfatter. Når han skrev under brevene sine, skrev han Thormod Torffueson. 
nere. Han hadde arvet gården Stangeland på Karmøy etter sin første kone (Titlestad 2001: 10). Tormod var født på Island, han studerte i København, og levde de siste 50 årene av sitt liv på Karmøy i Rogaland. Han arbeidet som historiker, og er særlig kjent for storverket Historia Rerum Norvegicarum, som er en norgeshistorie i fire bind, i sin helhet skrevet på latin.

Vi har ingen opplysninger om hvilket språk ekteparet Tormod og Anna snakket sammen. Men vi vet at Tormod behersket både dansk og latin i tillegg til morsmålet sitt, islandsk, og at han også publiserte på engelsk (Titlestad 2001: 15). Brevvekslingen mellom Tormod og Arne Magnusson, som er publisert sammen med brevene fra Anna til Arne, er for det meste skrevet i en varietet vi kan tillate oss å kalle en dansk-islandsk blanding. Både Tormod og Arne bodde i Danmark-Norge, og det kan ha preget skriftspråket deres. Dessuten har moderne islandsk vært gjenstand for omfattende purisme rettet blant annet mot danske innslag (Ottosson 1997). Hvis talemålet til Tormod lignet den dansk-islandske varieteten han skrev, har han nok kunnet kommunisere godt med folk i Norge uten for store tilpassinger. Anna på sin side har mest sannsynlig snakket den daværende stavangerdialekten. Hvorvidt de фvre sosiale klassene på den tiden hadde begynt å bruke et mer skriftnært, og derfor danskpreget, talemål, er usikkert. Det er først fra andre halvdel av 1700-tallet at vi har kunnskap om en slik sosiolekt.

Islendingen Arne Magnusson (på islandsk Árni Magnússon) var en av datidens viktige lærde i Danmark-Norge. Han og Tormod brevvekslet om innholdet i Tormods norgeshistorie, og de diskuterte andre saker av både kulturell og politisk art. Da Tormod ble syk og etter hvert døende, var det Anna som sto for brevskrivningen til Arne Magnusson. Disse brevene er innholdsmessig preget av pengesorger; som enke etter en mann med beskjedne midler hadde Anna lite og ingenting å leve av, og det var viktig å få solgt bøkene som mannen hadde skrevet. I og med at det ikke var kjøpere på Karmøy, ble bøkene sendt til København for at Arne skulle selge dem der.

\section{Brevene - Kålunds utgivelse}

Lesningen og analysene av Annas brev er basert på en utgivelse av den danske filologen Kristian Kålund (1844-1919). Han arbeidet som biblio- 
tekar ved den arnamagæanske håndskriftsamlingen, som inneholder både middelalderhåndskrifter som Arne samlet, og Arnes egne tekster (Blöndal 1919).

Brevene mellom Tormod og Arne er som nevnt skrevet i en danskislandsk blandingsvarietet. Språket er preget av lånord fra dansk og tysk, og av passasjer med kodeveksling til dansk. De siste brevene i denne brevvekslingen er i sin helhet skrevet på dansk, uten at det kommer klart frem hva som er grunnen til det. Brevene mellom Tormod og Arne er publisert i sin helhet, slik at en kan følge hele den skriftlige samtalen. Når det gjelder brevvekslingen mellom Arne og Anna, derimot, så inneholder den $\mathrm{i}$ alt 14 brev. 13 av disse er fra Anna til Arne, bare ett er fra Arne til Anna. Av de 13 brevene fra Anna til Arne er det bare ett hun, ifølge Kålund, ikke selv har ført i hånden. Min analyse tar for seg de 12 egenhendige brevene.

Ifølge Blöndal (1919) var Kålund ikke tilhenger av hardhendt normalisering til en norrøn standard, slik det var vanlig å gjøre det på den tiden. Han $\emptyset$ nsket en gjengivelse som lå tettere på originaltekstene, både ved gjengivelse av gammel islandsk litteratur og ved gjengivelse av yngre tekster. Selv om dette gjør det sannsynlig at avstanden fra håndskriften til publisert versjon er mindre enn i mange andre utgivelser, er det på ingen måte uproblematisk å basere språklige analyser på publiserte tekster i stedet for håndskrifter. Ingen utgivelse av håndskriftmateriale er helt nøytral (se for eksempel diskusjon i Nesse 2012), men det er et stort sprang fra en faksimile via en diplomatarisk til en normalisert gjengivelse.

I en grundig innledning gjør Kålund heldigvis greie for hvilken praksis han har brukt i gjengivelsen av brevene. I innledningen til brevutgaven skriver Kålund at han ikke har normalisert i det hele tatt, med få, definerte unntak: Han har satt inn tegnsetting, og han har gjort endringer i en spesifikk bokstavforbindelse, nemlig $s c h$. Han skriver at han ikke kan se $c$ i disse håndskriftene, men han har valgt å transkribere det han ser som $s h$, som $s c h$ i noen, men ikke alle brevene. Grunnen til å skrive $s c h$ og ikke $s h$ i utgivelsen var at skrivemåten $s c h$ var sedvane på den tiden brevene ble skrevet. Min egen erfaring med datidens håndskrift tilsier også at c'en i sch-forbindelsen, som var den vanligste for å gjengi dansk sk-lyd i ord som skulle og skib, var mer eller mindre grafisk assimilert med høy $s$ og h, og altså ikke lett - eller mulig - å få фye på. Kålunds lesere som han regnet med primært var interessert i brevene til Arne og Tormod 


\title{
Agnete Nesse
}

- ville muligens reagere hvis ord som schulle, schal, schib hadde blitt skrevet $<$ shulle $>$, $<$ shal $>$, $<$ shib $>$, fordi det var uvant.

Denne restitueringen av $s h$ til sch har han likevel bare foretatt ved utgivelsen av mennenes brev. I disse brevene har han også rettet opp en del andre ting som han gjør grundig rede for, men som ikke er relevant her. I brevene skrevet av Anna har Kålund valgt å skrive $<\mathrm{sh}>$, ikke $<\mathrm{sch}>$. Det vil si at for Kålunds lesere vil hennes rettskrivning se enda mer ubehjelpelig ut sammenlignet med mennenes tekster enn det som ville vært tilfellet hvis Kålund hadde holdt seg til samme utgivningspraksis gjennom hele boken. Når han skriver om Annas rettskrivning, uttrykker Kålund en holdning til skriftspråket som i dag virker noe krass:

Anna Hansdatters breve, som viser mangel på alle ortografiske forudsætninger, er aftrykte bogstavret, dog med normaliseret interpunktion; nogle af de forekommende besynderligheder skyldes vistnok påvirkning af talesproget. (Kålund 1916: VII).

For å gi leseren et mer fullstendig bilde av Annas språk, gjengir jeg her ett av brevene i sin helhet (Kålund 1916: 416-417):

\begin{abstract}
A Monsieur!
Hans gode shriffuelse datt. 8 aprilis er mig vell indhendigt, och iche haffuer faaet it ord siden, som er en lang tid siden. Soren shriffueren haffuer iche veret hos mig siden, huad hans tanche er ved jeg iche. Jeg lengis jertteligen och hver dag bær sorig i mit hiertte for min allerkierste frome mand, som gud rygte saa hastig fra mig; gud ver min hielp och trøst i Jessu nauf. Jeg vill formode, at hand for min sal. kierste bliffuer min ven och giør sit beste for mig. Jeg vill $\varnothing$ nshe, at min gode sal. kierste b $\varnothing$ ger var hos hand; saa jeg gierne, at de var til hans tienste. Jeg vil och gierne vide, om der er nogen penge enu til bage hos hand. Jeg er nu slet bar for penge och giffer store shatter ud til høsten, som er dage shat och andre shatter och ved inted hos nogen mensher at faa nogen penge. Jeg vill for mode, at hand iche tar min ublue shriffuelse ille op. Jeg stoller paa min frome sal. Kierste gode venshab med hand. For min store dristighed bedis ydmyg om forladelse. Her med aff bryde och nest flittig hilsen for bliffuer
\end{abstract}

Deris velædelheds ærbødigst tienerinde Anna sal. Tormods. Stanland d. 4. Aug. 1719. 
[Utenpå:]

\author{
A Monsieur \\ Mons. Arnas Magnusson \\ Professeur et Secrataire des Archives du Roy a Copenhague. \\ At af legges I Canike-Strædet eller ved vor frue kirke.
}

\title{
5 Språklig analyse - rettskrivning
}

\subsection{Stumme konsonanter}

Vi skal nå først se på selve rettskrivningen til Anna, og hva den kan fortelle oss, før vi ser på syntaks og ordforråd. En første gruppe interessante språktrekk er det vi kan kalle stumme konsonanter. Mange av disse konsonantene ble uttalt i eldre tid, og forsvant litt etter litt fra talemålet. Det er også store dialektforskjeller når det gjelder skjebnen til disse konsonantene. Det ser vi tydelig for eksempel når det gjelder ordene som i dag skrives med $h v$ - i bokmål. I noen dialekter er $b$ en stum konsonant, fordi uttalen er med $v$. I andre dialekter er $b v$ historisk erstattet med $k, k v$ eller $\stackrel{\circ}{a}$, og $i$ atter andre står $b$ uten $v$. Men det er ikke alltid dialektforskjeller: I ord som gjerne og bjerne er $g$ og $h$ stumme i alle norske dialekter, mens utviklingen har vært annerledes i de andre nordiske språkene (Kristoffersen og Torp (2016: 189). Grunnen til at de to ordene staves forskjellig, er fordi de ble uttalt forskjellig tidligere, og at språknormererne har valgt å opprettholde den historiske skrivemåten slik at de to ordene ikke blandes sammen i skrift. Når slike valg først er tatt, tar vanen over og styrer folks preferanser for rettskrivning.

I tabell 1 er skrivemåten i Annas brev sammenlignet med de skrivemåtene som finnes i samtidens ordbøker. Formene fra Annas brev er delt $i$ tre grupper: I den første kolonnen står de ordene der Anna har tatt med stum konsonant, i den andre kolonnen mangler en eller flere stumme konsonanter. I den tredje kolonnen er det skrevet inn en stum konsonant som ikke gjenfinnes i noen av de benyttete ordbøkene fra den tiden. Det er bare tatt med en forekomst av hvert ord. Flere av disse ordene går igjen $i$ alle brevene, for eksempel er der alt i alt 10 forekomster av pronomenet 'han', det er alltid skrevet hand. Mens når det gjelder 'hjerte' og 'hjertelig', 


\section{Agnete Nesse}

er det slik at det er 3 forekomster av biertte, 1 forekomst av bierttelig og 3 forekomster av jerttelig.

\begin{tabular}{|l|l|l|}
\hline Vanlig form i samtiden & Stum konsonant mangler & Hyperkorrekt form \\
\hline tienner inde & best (bedst) & farder (farer) (subst) \\
\hline dristighed & dristihed & hued (ved) \\
\hline hand & en (end) & \\
\hline godhed, gode & got (godt) & \\
\hline ilde (ille) & inpage (indpakke) & \\
\hline hielp, hielpe & joulbet (hjulpet) & \\
\hline hiertte, hiertteligen & jertteligen & \\
\hline huer, huad, huor, huilchet & & \\
\hline ald & Islans (Islands) & \\
\hline findis & op hol (ophold) & \\
\hline styermand & schyll (schyld) & \\
\hline tønder & sel (selv) & \\
\hline andet & stese (stedse) & \\
\hline sandhed & søll (sølv) & \\
\hline kand, kunde & til fres (til freds) & \\
\hline vestands (velstands) & velstans & \\
\hline sinde (sinne) & ydmygelien & \\
\hline falder (faller) & inbonne (innbundne) & \\
\hline & bonner (bunner) & \\
\hline
\end{tabular}

Tabell 1: Stumme konsonanter i Annas brev. Former ifet skrift markerer variasjon på ett og samme ord, og bøyningsformer av samme ord.

Den første kolonnen inneholder skrivemåter som er representert i en eller flere av ordbøkene fra Annas samtid. Det er ikke gitt at alle de såkalt stumme konsonantene var stumme den gang. For eksempel vet vi at påvirkningen fra skriftspråkets $n d$ på 1900-tallet (og muligens på 1800-tallet) førte til uttalt $d$ i ord som opprindelig, noensinde, sindelag, ualmindelig, almindelig og forbinder (alle eksemplene fra NRK Radio fra perioden mellom 1940-1990), og fremdeles kan for eksempel uttalen /veninde/ høres blant eldre språkbrukere. ${ }^{5}$ Ordet tjenerinde kan også være et rent litterært eller religiøst ord for henne, all den tid taus ifølge Knud Leems ordliste ser ut til å ha vært det vanlige på Karmøy på hennes tid (Hannaas 1923: 228).

5. Da $<$ nd $>$ ble endret til $<$ nn $>$ i 1917 , var venninne ett av de ordene som fikk valgfri skrivemåte. En kunne altså velge mellom $n n$ og $n d$ siden «d uttales i en del avledede ord» (Den departementale retskrivningskomite, 1918: 16-17). I talemålsprøven fra Frogner (Sandøy 1996: 188) brukes /veninde/. I et pågående arbeid med minneb $\varnothing$ ker finner jeg at skrivemåten <venninde > brukes hyppig også etter 1938 da < venninne> ble eneform. 
Den andre kolonnen inneholder skrivemåter der en eller flere konsonanter som ikke blir uttalt i dag, men som det var vanlig å skrive på 1700-tallet, mangler. Heller ikke her har vi absolutt sikkerhet for at disse konsonantene ikke ble uttalt av Anna, men vi kan tillate oss å regne med at det er slik. I tre tilfeller, $<$ dristighed $>/<$ dristihed $>,<$ hiertteligen $>/$ $<$ jertteligen $>$ og $<$ vestands $>/<$ velstans $>$ ser vi at samme ord dukker opp i begge kolonnene. Dette kan tolkes som en utføringsfeil (se innledningen for en forklaring på dette begrepet).

Den tredje kolonnen inneholder bare to ord, $<$ farder $>$ og $<$ hued $>$. Disse kan kalles for hyperkorrekte former i den forstand at de ikke skulle skrives med henholdsvis $d$ og $h$, og er altså feil som viser at kompetansen om stumme konsonanter ikke er perfekt. Det første ordet opptrer i følgende setning: Saa som her nu forre falder denne skynne leilighed med en Islans farder. Det er altså ordet 'islandsfarer' hun har skrevet, en vanlig betegnelse for en som handlet på Island. Tilsvarende kjenner vi til Nordfar fra Bergen om de som handlet på Nord-Norge, og Bergerfarer fra Lübeck om de som drev handel i Bergen. Verbet fare har aldri hatt noen $d$, det het fara i norrønt og fare i eldre dansk. Substantivet farer er en såkalt nomen agentisdanning av dette verbet, og dette avledete substantivet har heller ikke hatt $d$. Det er mulig det er s $\varnothing \mathrm{kt}$ å prøve å forklare hvorfor Anna har satt inn en $d$ i dette ordet, men på et vis virker ikke $d$ helt malplassert her. Grunnen er at vi har substantivet ferd, avledet av å fare, og $d$ kan ha blitt skrevet inn i substantivet farer i analogi med substantivet ferd. Det er ingen grunn til å tro at hun har uttalt $d$ i farer, mens derimot $d$ i ferd kan ha vært uttalt. Den norrøne formen var ferð, genitivsformen var ferðar, og sammensetninger som ferðarleyfi 'reiseløyve' kan ha vært i bruk i formen ferdarløyve i 1700-tallets rogalandsk. Derfra til å skrive Islans farder er kanskje ikke så langt.

Det andre ordet i den tredje kolonnen er preposisjonen hued, som opptrer i setningen at der ennu schulle uerre god for haabning for mig hued cammeret. Heller ikke denne skrivemåten er direkte overraskende. Vi kan anta at ordet ble uttalt/ve:/ eller/ve:d/, hvis dette i det hele tatt var en vanlig preposisjon i slike uttrykk. Fra moderne norsk vet vi at mange vestnorske dialekter oftest har /me:/ eller /me:d/ i slike uttrykk ('oppe med kirken', 'nede med skolen', 'der med Bunnpris'), og skriftspråkets sedvanlige ved ('oppe ved kirken' osv.) stammer fra dansk og/eller østlandsk. Det er altså mulig at ved i denne setningen ikke tilsvarer den muntlige uttrykksmåten hennes, men at hun vet at en en del funksjons- 
ord skrives med $h v$ (i datidens skriftsystem ofte realisert som $b u$ ). En slik analyse viser en skriftform som kan være mer frekvent hos voksne uerfarne skrivere enn hos barn, fordi de analogidanningene som gjøres, krever noe mer. ${ }^{6}$

Ut fra Annas rettskrivning kan det se ut som om vanskeligheten med å skrive bokstaver som ikke har en tilsvarende lyd i talemålet, ikke er jevnt fordelt på ordtyper. Hvis hun vet at ord som uttales kor eller kvar skal skrives med $b u$, så kan denne kunnskapen brukes alle steder der tilsvarende lyder skal skriftfestes. Men når en lyd i talemålet har mange ulike representasjoner i skrift, blir det vanskeligere: Det ikke alle ord som har $j$ i fremlyd som skal skrives hj. Mange skal skrives gj (gjøre, gjerne) og noen skrives med $j$ (jordber, jul).

Når det gjelder formen til freds, som Anna skriver < til fres>, så er det all grunn til å tro at det gjenspeiler uttalen, og at en moderne uttale /jei er tilfreds me de/ er skriftpåvirket. Setningen uttrykket er brukt i, er slik: Huad sig angaar di sedler hand schriffuer om, er jeg meget vell til fres. ${ }^{7}$ Her har moderne norsk beholdt en $d$ - kanskje for å markere den morfologiske sammenhengen med substantivet fred, til tross for at ordet har sin opprinnelse i det middelnedertyske lånordet tovreden, som i tillegg til å bety 'forn $\varnothing y d$ ' hadde betydningen 'beroliget'. Det er sannsynlig at ordet er lånt inn i norsk tidlig, i hvert fall hvis vi skal tolke $-s$ i til freds som en gammel genitivsendelse styrt av til. En annen mulighet er at det er et senere innlån som har fătt $-s$ i analogi med lignende uttrykk.

Formen bunn eksisterte ikke i verken dansk eller norsk - det gammelnorske ordet var botn, gammeldansk hadde botn og bodn; og det samtidig danske ble skrevet bund. Fornorskingen av dette ordet innebar valg mellom botn og bunn, den siste formen er en tilpassing til uttale /bun/, med midtre $u$, assimilert $t n$ og ingen palatalisering av $n n$. Her er altså Anna, med sin skrivemåte $<$ bunner $>$, langt foran sin tid.

6. I de nevnte minnebøkene, der data er ca. 1200 minner fra 1800- og 1900-tallet, er innsetting av $b$ i ordene vet (verb) og ved (preposisjon) relativt hyppig.

7. Eldre bergensk hadde uttale med /i/, som i uttrykk som te friss eg lå sa kjerringen, hon satt $i$ sengen. 


\subsection{Lenisering}

Bruken av stemte eller ustemte plosiver, altså $p, t, k$ mot $b, d, g$, er en gjenganger i norsk språkhistorie, og i forskningen på tekster skrevet i Norge $\mathrm{i}$ dansketiden (Nesse 2011). Bakgrunnen er at ustemte plosiver i enkelte posisjoner gikk over til å være stemt i dansk, mens de i de fleste norske dialekter ble værende ustemt. I skriftspråket, også slik det ble skrevet i Danmark, skjedde dette gradvis, med mye variasjon knyttet både til plassering i ordet og skrivernes personlige rettskrivning. For eksempel kan en på 160o-tallet finne danske stavemåter som Maade 'måte' med $d$, men med bevart $k$ foran $t$ : frykte, Dikt (Ruus 2018: 68).

Fra stemte plosiver forandret den danske uttalen seg videre, og resultatet ble blant annet diftonger og frikativer, men bokstavene $b, d, g$ ble beholdt. Da det ble vanlig å bruke leseuttale i Norge i løpet av andre halvdel av 1700-tallet, var det skriften som ble lagt til grunn, ikke dansk uttale. Det var altså i Norge man kunne høre uttalemåter som /spro:g/ og /bo:g/ (Larsen \& Stoltz 1911-1912: 68; Haraldsrud 2012: 56); dette er trolig noe av bakgrunnen for et svært mye sitert utsagn om at den vakreste dansken ble snakket i Norge (se for eksempel Nesse \& Torp 2018: 422).

I forskningen på norske innslag $\mathrm{i}$ tekster skrevet av norske skrivere $\mathrm{i}$ dansketiden har funn av $p, t$ og $k$ i posisjoner der det danske skriftspråket hadde $b, d, g$, vært et tegn på dialektinnslag. Jakobsen (1952: 52) skriver for eksempel at

De stemmeløse plosivene $\mathrm{p}, \mathrm{t}, \mathrm{k}$ er jo ved siden av diftongene kanskje det viktigste språklige skillemerke mellom norsk og dansk. Vi finner også hos $\mathrm{P}[$ etter]. D[ass]. en del ord skrevet med «hard» konsonant.

Han går videre til å notere eksempler som Naper, Ryper og stenbit. Pettersen (1957: 37) finner derimot lite av slikt hos Dorothe Engelbretsdatter, og skriver at «Når det gjelder forholdet ved postvokalisk $p, t, k,: b, d, g$, kommer hun således så godt som aldri i skade for å skrive "feil».» Brevene til Anna er ekstra interessante med hensyn til dette språktrekket. Grunnen er at Anna, i motsetning til både Petter Dass og Dorothe Engelbretsdatter, var vokst opp i et område av Norge med lenisering. Vi skal se nedenfor at Rasch 1698 (Venås 1990: 62-64) kan fungere som en indikator for hvordan Anna kan ha snakket, og den rogalandsdialekten som han gjengir, har lenisering. Hvis det også gjelder Anna, var hennes 
system i tråd med det danske skriftspråket, og da er det ingen grunn til å anta at det kan være dialekten hennes som er grunnen hvis hun fordeler $b, d, g \circ g, t, k$ på en annen måte enn det som var vanlig i datidens skriftspråk. Hun bodde riktignok på Karmøy, like nord for den såkalte leniseringsgrensen, som går et stykke nord for Skudeneshavn. Det er derfor sannsynlig at hun har vært omgitt av språkbrukere både med og uten lenisering. Et tegn på at hun har lenisering som del av sin norske dialekt, er at hun leniserer norske ord: De danske ordbøkene har kun formene foged og fogd, mens moderne norsk har fut. Anna skriver det norske ordet, men med lenisert plosiv: $<$ fud $>$.

Bruken av bokstavene $p, t, k \operatorname{og} b, d, g$ har også fått oppmerksomhet $\mathrm{i}$ forskningen på skriveinnlæring, fordi det viser seg at barn i en tidlig fase ofte bytter de såkalt homorgane konsonantene med hverandre. Dette gjelder ikke bare i Norge, Treiman (1993: 144-148) beskriver det samme hos engelske begynnerskrivere. Elsness (2002: 125f.) kaller fenomenet for parvis plosiverstatning. Det er minst tre grunner for at $p \operatorname{og} b, t \operatorname{og} d$, og $k$ og $g$ kan bytte plass. Det ene er det grafiske, dette gjelder $p$ og $b$ som, når man skriver små bokstaver, stavskrift eller løkkeskrift, er svært like. Det er større grafisk avstand mellom de to andre parene. En annen grunn er nettopp at de er homorgane, altså at lydene uttales på samme sted i munnen, det er forhold som stemmebåndsvibrasjon og aspirasjon som gjør dem forskjellige. I en del posisjoner er opposisjonen mellom stemthet og/eller aspirasjon opphevet, og det vil da være likegyldig ut fra et fonologisk synspunkt hvilket grafem en velger for å realisere den allofonen som høres.

Barn som lærer å skrive i dag, har - med unntak av de som snakker dialekter med lenisering - et skriftspråk som korresponderer bra med talen med hensyn til plosivene. Unntakene er posisjoner der forskjellen mellom dem er opphevet. Vi forklarer derfor skrivemåter som sgole og sbise med at barnet er på det fonologiske nivået, hun eller han skriver det vedkommende hører, nemlig manglende aspirasjon, noe barnet tolker som stemthet.

Teoretisk sett vil dette også kunne være tilfellet med en uerfaren skriver for tre hundre år siden. Som norske barn i dag hadde hun et talemål som korresponderte med skriften på dette punktet: Annas distribusjon av stemte og ustemte konsonanter var, sikkert med noen unntak, felles med skriftspråkets. Vi skal nå se nærmere på akkurat disse konsonantene i Annas brev, og se hvordan vi kan forklare skrivemåtene hennes. 


\begin{tabular}{|l|l|}
\hline $\begin{array}{l}\text { Anna bruker en form } \\
\text { som var vanlig } \mathbf{i} \\
\text { samtiden }\end{array}$ & $\begin{array}{l}\text { Parvis plosiverstatning (vanlig form i samtiden } \\
\text { står i parentes) }\end{array}$ \\
\hline aarsager & bregen (præken) \\
\hline bøger & bresten (presten) \\
\hline copi bog & cobibog (kopibog) \\
\hline dristighed & følchende (følgende) \\
\hline for haabning & inpage (indpakke) \\
\hline Kiøbenhafn & inted (intet) \\
\hline lade & Kiøpenhauf (Kiøbenhavn) \\
\hline lig & \\
\hline lige & \\
\hline naad & \\
\hline nøgelen & \\
\hline sag & \\
\hline $\begin{array}{l}\text { sandhed, fromhed, } \\
\text { drestihed }\end{array}$ & \\
\hline schibe, schib & schiber (skipper) \\
\hline søgte & sebtemer (september) \\
\hline ud & trøg (tryk) \\
\hline umage & vegsel (veksel) \\
\hline ved & \\
\hline venschab & \\
\hline vide & \\
\hline
\end{tabular}

\section{Tabell 2: Lenisering i Annas brev}

Av Tabell 3 ser vi at Annas skrivemåter overveiende er i tråd med samtidens sedvane, slik vi finner den i ordbøkene nevnt i innledningen. I et tilfelle som < schiber > kan det være grafisk analogi som spiller inn - hun har skrevet både verbet skibe og substantivet skib korrekt, og overfører bruken av $b$ til substantivet skipper. Når det gjelder bynavnet København, så var der ulike skrivemåter i bruk i samtiden, så her skyldes sannsynligvis ikke variasjonen at Anna er usikker, men at det var konkurrerende former i bruk. I brevvekslingen mellom Tormod og Arne brukes for eksempel den franske formen Copenhague. Skrivemåten $K(j) ø b e n h a v n$ er jo nettopp et resultat av leniseringen i dansk - derfor skrives bynavnet med $p$ i andre språk, som i engelsk Copenhagen og svensk Köpenhamn.

De tre skriveformene cobi bog, bregen og bresten er de som er de mest åpenbare kandidatene til å være grafiske ombyttinger, i og med at $b$ og $p$ også i datidens håndskriftstil hadde viktige likhetstrekk. Skrivemåtene

8. I dette og flere av de andre ordene er vokalen kort. Ifølge Skjekkeland (1997: 111) er lang eller forlenget vokal «ikkje eit vilkår for endringa [leniseringen], jf. at det på kysten av Agder heiter sidde v. (sitja)...” 
sebtember og vegsel skyldes oppheving av forskjell mellom stemt og ustemt konsonant når konsonanten kommer i kontakt med annen ustemt konsonant, i dette tilfellet $t$ og $s$.

Dette viser at det slett ikke er slik at avvik i rettskrivningen av $b, d, g$ og $p, t, k$ hos norske skrivere trenger å betraktes som norskheter. Selv skrivere med lenisering i dialekten gjør feil, og det er feil også innlærere i dag kan gjøre. Her spiller grafiske, analogiske og fonotaktiske faktorer inn. Når Anna skriver følchene er det ingen grunn til å anta at hun uttalte ordet med $k$. Hun velger likevel ikke en tilfeldig bokstav i konsonantinventaret, hun velger den nest beste konsonanten og illustrerer derved den tette forbindelsen mellom de stemte og ustemte plosivene i den språklige bevisstheten.

\subsection{Bokstaver som mangler}

At bokstaver mangler i eldre tekst, er ikke uvanlig. Som nevnt i innledningen er forkortelser kjent helt fra den aller tidligste skrivningen, og det er vel kjent at forkortelser i tiden før papir ble brukt, var vanlig blant annet for å spare pergament. Men også senere ble forkortelser brukt. Ofte ble de markert, for eksempel ved hjelp av en strek over ordet eller deler av ordet, og også i publiserte bøker kan en finne forkortelser, særlig av doble nasaler. Disse er ofte markert ved hjelp av en såkalt nasalstrek over den gjenværende nasalen. Det å sette inn en slik strek, viser en bevissthet om at nasalen hører hjemme i skriftbildet, realisert enten som bokstav eller som forkortelsestegn. I Annas brev er det flere tilfeller av bokstaver som mangler, noen av disse er nasaler, men også andre konsonanter utelates uten at forkortelsestegn brukes. I tillegg utelates vokaler. Anna har også en del eksempler på at hun ikke bare utelater en bokstav, men skriver inn feil bokstav i stedet.

Nasalene viser seg å være utelatt sjeldnere enn en kunne forvente ut fra eldre skriftkonvensjon. Også fra studier av engelsk begynnerspråk ser det ut til at nasalutelatelse er mindre hyppig enn forventet. Treimann (1993: 217) som unders $\varnothing$ kte førsteklassinger, fant at prosentdelen for utelatelse av $n$ var relativt lav, selv om den $\varnothing$ ket noe da hun utelot det frekvente and, som elevene tilsynelatende allerede hadde automatisert.

De få tilfellene av nasalutelatelse som Anna har, ser ut til å være av ulike typer: I den forkortete skrivemåten Stavfager er det nasale elementet av ng-lyden utelatt; det er et eksempel på at det ikke er korrelat (Elsness 2002: 120) mellom grafem og fonem, noe som $\phi$ ker feilfrekvensen 
En ANALYSE AV SPRÅKet I ANNA Hansdatter TORMOdS BREV

\begin{tabular}{|c|c|c|c|c|}
\hline $\begin{array}{l}\text { Manglende } \\
\text { nasal }\end{array}$ & $\begin{array}{l}\text { Manglende } \\
\text { annen } \\
\text { konsonant }\end{array}$ & $\begin{array}{l}\text { Manglende } \\
\text { vokal }\end{array}$ & $\begin{array}{l}\text { Flere manglende } \\
\text { bokstaver }\end{array}$ & Feile bokstaver \\
\hline $\begin{array}{l}\text { Kiøpenhauf } \\
\text { (Kiøbenhafn) }\end{array}$ & sørste (største) & $\begin{array}{l}\text { kierste } \\
\text { (kieriste) }\end{array}$ & $\begin{array}{l}\text { begieng } \\
\text { (begiering) }\end{array}$ & beflige (beflitte) \\
\hline nauf (navn) & vor (vort) & $\min ($ mine $)$ & $\begin{array}{l}\text { tiensvillste, } \\
\text { tienstvilse } \\
\text { (tienistevilligste) }\end{array}$ & flitte (flittig) \\
\hline $\begin{array}{l}\text { Stavfager } \\
\text { (Stavanger) }\end{array}$ & $\begin{array}{l}\text { velele } \\
\text { (veledle) }\end{array}$ & $\begin{array}{l}\text { Canke } \\
\text { stræde } \\
\text { (Cannicke } \\
\text { stræde) }\end{array}$ & inu (endnu?) & $\begin{array}{l}\text { stifschifrenn } \\
\text { (stiftskriveren) }\end{array}$ \\
\hline $\begin{array}{l}\text { øsche } \\
\text { (ønske/ynske) }\end{array}$ & ville (vilje) & menscher & $\begin{array}{l}\text { tiestæbødigt } \\
\text { (tjenesteærbødigst) }\end{array}$ & tviende (tvende) \\
\hline \multirow[t]{8}{*}{$\begin{array}{l}\text { tiest } \\
\text { (tjeneste/tjenst) }\end{array}$} & $\begin{array}{l}\text { tiesschyldigst } \\
\text { tieneinde } \\
\text { (tjenstskyldigst } \\
\text { tjenerinde) }\end{array}$ & $\begin{array}{l}\text { augstu } \\
\text { (Augusti) }\end{array}$ & $\begin{array}{l}\text { tieninde } \\
\text { (tjenerinde) }\end{array}$ & elleris (ellers) \\
\hline & $\begin{array}{l}\text { kiømandens } \\
\text { (kjøbmandens) }\end{array}$ & & & $\begin{array}{l}\text { liglighed, lielighed } \\
\text { (lejlighed) }\end{array}$ \\
\hline & $\begin{array}{l}\text { forladesse } \\
\text { (forladelse) }\end{array}$ & & & $\begin{array}{l}\text { tieller, } \\
\text { tliffuer(tvivler/tviler) }\end{array}$ \\
\hline & $\begin{array}{l}\text { cosomtion } \\
\text { (konsumption) }\end{array}$ & & & $\begin{array}{l}\text { augustu } \\
\text { (august/Augusti) }\end{array}$ \\
\hline & $\begin{array}{l}\text { vestans } \\
\text { (velstands) }\end{array}$ & & & $\begin{array}{l}\text { kameer } \\
\text { (kammeret/kamret) }\end{array}$ \\
\hline & $\begin{array}{l}\text { torligen } \\
\text { (storligen) }\end{array}$ & & & $\begin{array}{l}\text { agsomtert } \\
\text { (accepteret) }\end{array}$ \\
\hline & $\begin{array}{l}\text { sebtemer } \\
\text { (september) }\end{array}$ & & & $\begin{array}{l}\text { obliserte ven } \\
\text { (obligerte ven) }\end{array}$ \\
\hline & vor (vort) & & & bibliotet (bibliotek) \\
\hline
\end{tabular}

Tabell 3: Manglende bokstaver sammenlignet med vanlige former ifølge ordbøkene

hos uerfarne skrivere. I de andre tilfellene er det en n-lyd som skal representeres av en n-bokstav, som er utelatt. Det er mulig at Anna har uttalt $n g$-lyden uassimilert, altså som /.gg/. Skjekkeland (1997: 118) skriver riktignok at uassimilert uttale var vanlig mellom Sunnmøre og Sunnhordland, men det er ikke usannsynlig at denne uttalemåten har vært vanlig også lenger sør på Annas tid. I så fall har det vært korrelat mellom skriftspråkets $<\mathrm{ng}>$ og talens $/ \mathrm{yg} /$.

I tre av ordene, $<$ ki $\varnothing$ mandens $>,<$ cocomtion $>$ og $<$ sebtemer $>$ er det en $b$ eller en $p$ som utelates i m $\varnothing$ tet med en $m$. Både $b, p$ og $m$ er bilabiale lyder, henholdsvis plosiver og nasal, og det er ikke umulig at det er denne artikulasjonsmessige likheten som gjør at plosivene ikke blir representert i Annas skriftbilde. 
Elsness skriver (s. 147) på bakgrunn av sitt materiale, at det er mye hyppigere at konsonanter som opptrer i gruppe, blir utelatt, enn at enkeltstående konsonanter utelates. Dette stemmer også med Annas rettskrivning. Alle de utelatte konsonantene, også nasalene, skulle stått sammen med andre konsonanter. På den annen side finner Elsness at de fleste utelatelsene befinner seg i slutten av ordet (rim), dette stemmer ikke med eksemplene fra Anna.

Når det gjelder vokalbortfall, kan en mistenke at skrivemåten i st $\varnothing$ rre grad reflektererer talemålsformer, ikke minst siden flere av dem minner om former som det er vanlig å høre i dag. Både /mensker/ og /çærste/ eller /çæ:ste/ er mulige uttalemåter i dag. En annen tilnærming er å se på antall stavelser i de berørte ordene, enten isolert eller kombinert med trykk (Treiman 1993: 191). I eksemplene fra Annas brev er det den trykklette vokalen $i$ andre stavelse i et trestavelsesord som forsvinner. Det gjelder også gateadressen $<$ Canke stræde $>$. Det siste eksemplet, skrivemåten <augsti>, er også et trestavelsesord, men her er det godt mulig at uttalen har hatt trykk på andre stavelse. I så fall er det mye vanskeligere å forklare hvorfor akkurat denne vokalen skulle falle bort. Her kan det imidlertid spille inn at tradisjonen for å forkorte månedsnavn, riktignok på andre måter enn dette, var etablert på Annas tid.

Eksemplet < vor > for vort plassert i kolonnen "andre konsonanter" og eksemplet <min > for mine i kolonnen "vokalbortfall" hører kanskje ikke med her, i og med at det dreier seg om manglende bøying, altså morfologi. Det er flere tilfeller i disse brevene der Anna ikke samsvarsbøyer. Hun skriver altså nogen aff min bøger og vi haffuer maaet taget vor søll og saalt til schatterne. Hun markerer heller ikke nødvendigvis genitivskonstruksjoner, men kan skrive min frome sal. kierste gode venschab med hand. Det mangler også andre bøyingsendelser, for eksempel $r$ i presens. På denne tiden hadde de rulle-r i Rogaland, så det er lite sannsynlig at utlydende $r$ ble assimilert av vokalen foran, slik det ofte skjer med skarre$\mathrm{r}$ (vokalisering). Men sammenligner vi med Jacob Rasch sin rogalandstekst fra 1698 (Venås 1990: 62-64), er det i hvert fall slik at presens $-r$ allerede da hadde falt bort, og det kan være dette som reflekteres i den ubøyde presensformen.

Jeg er tilbøyelig til å tolke noen av de manglende bøyingsformer og endelser som hyperkorrekte former: Sammenligner en datidens rogalandsmål, for eksempel slik det er gjengitt av Rasch, finner en at dialekten hadde en hel rekke bøyingskategorier som skriftspråket ikke hadde. Det 
å lære å skrive har delvis dreid seg om å slå sammen talemålets kategorier, for eksempel femininum og maskulinum; eller ulike typer presensendelser som skulle bli til en. Da vil en som lærer å skrive, selv om hun kjenner til hovedregelen for forenkling av bøyingssystemet, ikke alltid treffe med forenklingene. For Anna kan det å skrive < vor søll> selv om hun kanskje sa /vort/,9 være like naturlig som å skrive alde hvis hun sa /adle/ og iche hvis hun sa /içe/ eller/inçe/.

\subsection{Tydelig dialektpåvirkete skrivemåter}

En skulle gjerne tro at denne gruppen var svært stor, ikke minst siden Kålund antar at mange av de ukonvensjonelle skrivemåtene til Anna skyldes talemålet. Men slik er det ikke, faktisk er det bare følgende skrivemåter vi med god sikkerhet kan tilskrive rogalandsk dialektbakgrunn:

\begin{tabular}{|l|l|}
\hline Annas skrivemåter & Former i ordbøkene \\
\hline til ta til (å ta til) & at ta til \\
\hline Nore (Norge) & Norge, Norrige \\
\hline
\end{tabular}

\section{Tabell 4: Skrivemåter som kan forklares ved Annas dialektbakgrunn}

Den første av disse to skrivemåtene som ikke kan forklares på annen måte enn ved Annas dialekt, er bruk av infinitivsmerket til, trolig uttalt /te/. Mest sannsynlig uttalte Anna både infinitivsmerket og preposisjonen /te/, og hadde lært at preposisjonen te skulle skrives < til >. Det er derfor ikke rart at hun også velger skrivemåten $<$ til $>$ for infinitivsmerket te. Hun bruker for det meste det korrekte infinitivsmerket <at>, men en gang bruker hun altså <til>. Det var vanlig over store deler av Vestlandet å bruke infinitivsmerket te, i tillegg til å og at (Nesse 2002: 194213; Huus 2018: 80). Her er det all grunn til å anta at det har vært relativt mye variasjon i flere dialekter.

Landsnavnet Norge har vært både skrevet og uttalt på mange ulike måter gjennom tidene, og ulike dialekter har hatt ulike varianter (se Myrvoll (2011) og Schulte (2018: 124-127) for diskusjon om etymologien). Varianten med $-i$ er godt belagt (Sandøy 1997), men selv om uttalen har

9. Ordbog over det danske Sprog anfører riktignok at sølv i helt spesielle tilfeller har blitt brukt som maskulinum, men det oppførte eksempelet i ordboken: «Kaniner sælges .. stor fransk Sølv og lille Sølv», viser at det egentlig ikke er snakk om maskulinum på substantivet $s \varnothing l v$, men på kanin. 
vært med en tydelig artikulert $i$, var Anna vant til at de trykklette endevokalene ble skrevet som $e$, og kan ha overført dette mønsteret slik at en skrivemåte $<$ Nore $>$ greit kunne gjengi uttalen med $i$-endelse. Sand $\varnothing \mathrm{y}$ (1997: 91) tar det for gitt at en uttale med $g$ er hentet inn i yngre tid fra skriftspråket, og Annas skrivemåte er kanskje en støtte til dette.

\section{Språklig analyse - syntaks og ordforråd}

\subsection{Syntaks}

Syntaksen i brevene fra Anna er preget av korte enheter sammenlignet med det hennes samtidige brevskrivere presterer. På mange måter gjør det at brevene hennes oppleves som mer i tråd med vår tid: Hun skriver rett på sak og er tydelig på hva hun vil frem til. Brevene er også korte. Men vi kan anta at det som fremstår som tydelig og rett på sak for lesere i det tjueførste århundret, fremsto som enkelt på grensen til det uhøflige for den tidens lesere. Så her har tiden arbeidet med disse brevene.

Setningene er ellers preget av utelatelse av setningsledd. Det varierer hva som mangler, men både subjekt og verbal kan utelates. Hvorvidt dette skal ses på som innslag av muntlighet eller som uttrykk for at det er strevsomt å skape tekst, og noe lett blir borte, kan diskuteres. Her følger noen få eksempler som kan illustrere hvilke ledd Anna utelater:

\subsubsection{Utelatelse av subjekt}

(1) Hans gode schriffuelse datt. 8. aprilis er mig vell indhendigt, och iche haffuer [jeg] faaet it ord siden, som er en lang tid siden.

(2) Her med aff bryde[ $\mathrm{r}$ jeg] och nest flittig hilsen for bliffuer.

(3) Hans bøyterede schriffuelse dat. 26. Aug. er mig vell indhendigt och der aff for nemer [jeg] hans gode Affection; for min frome sal. kierste schyll vill jeg formode at [han ['du']] bliffve min ven.

Det er overveiende pronomen i første og andre person entall som utelates. I og med at dette er brev fra et 'jeg' til et 'du', er det ikke urimelig at hun utelater disse subjektene ut fra en opplevelse av at subjektet er gitt. 


\subsubsection{Utelatelse av verbal}

(4) Min kierste lader hands veledle meget flitte hilse, at hand ville vere aff den godhed at maatte for penge [ta imot] 4 exemplair aff hands bog.

Her er det et infinitt verbal som er utelatt, men det er ikke lett å forklare utelatelsen.

\subsubsection{Eksempler på muntlig syntaks}

En tydelig muntlig fremstillingsform finner vi når informasjon presenteres som oppramsing:

(5).. om den copi bog och min sal. kierstes sag om Samsø er nedkomen, som bleff schichet $i$ vaar i fasten med en styermand fra Kiøpenhaufved naufPeder Bensen.

Likhetstrekk med barnetekster finner vi også når ledd dubleres, for eksempel når hun skriver en setning der et løst sammensatt verb (komme ned) har partikkel på begge de mulige stedene:

(6) jeg ved for gud iche andet en den kom ned med de andre cobibøger ned.

\subsection{Ordforråd}

\subsubsection{Semantisk forskyvning}

Ved lesning av eldre tekst er det slik at en relativt greit kommer seg inn i både rettskrivningsm $\varnothing$ nstre, bøyingsm $\varnothing$ nstre og syntaktiske mønstre, selv om avstanden til moderne norsk er relativt stor. Det som skaper forståelsesproblemer, er i første omgang ordforrådet, og da er det særlig tre ulike typer endringer å unders $\varnothing \mathrm{ke}$ :

1. Ord for fenomen som fremdeles omtales, men der et nytt ord er tatt $\mathrm{i}$ bruk. Gamle måleenheter er for eksempel skiftet ut med nye.

2. Ord for fenomen som ikke lenger er aktuelle, her vil terminologi fra gamle industribedrifter kunne tjene som eksempel.

3. Ord som fremdeles brukes, men der betydningen har blitt forandret.

Et sjarmerende eksempel på det siste er at det ordet som brukes for 'ektefelle', både av Anna, Arne og Tormod, er kjereste, av Anna oftest skrevet 
$<$ kierste > Når Arne skriver til Tormod, og ber ham hilse til Anna, tilføyer han alltid dydedle foran kjereste. Anna skriver om Tormod som $<$ min kierste> så lenge han lever, og går så over til å omtale ham som $<$ min frome sal. kierste>. Her er det snakk om en semantisk forskyvning, i og med at et ord som den gang betydde 'ektefelle', har gått over til i dag å bety nettopp en man ikke er gift med, men som man har en lignende relasjon til. Det uventete for en nåtidig leser er kanskje at kjereste ble brukt om ektefeller nettopp i en tid da ekteskapene ikke nødvendigvis først og fremst ble inngått av romantisk kjærlighet, men av praktiske forhold.

Også ordet konsumption, som Anna skriver < cosomtion>, er kjent for oss i dag - det er synonymt med ordet forbruk. Men på hennes tid var det mer spesifikt, Ordbogover det danske Sprog angir at det var en skatt knyttet til forbruksvarer. Hun skriver:

(8) Her er ingen lindring for mig med cosomtion och schatter, siden min frome sal. kierste døde; jeg maa giffue alt det same.

Et siste eksempel på ord som brukes med annet innhold, er oppvart, som hun bruker i uttrykket < Guds tryge opvart>. A varte noen opp i moderne forstand er jo noe vi ser i restauranter og selskaper, og ikke noe vi forbinder med Gud. Men hovedinnholdet 'å gjøre noe bra for en annen', er den samme. Et eksempel fra Medisinalmelding 1804 viser at opvartning brukes slik som Anna bruker opvart, og at den semantiske forskyvningen av dette ordet har gått for seg i løpet av de siste to hundre årene:

(9) ... dog døde den første ikke saameget av Sygdommens Heftighed, som formedelst slet Pleye og Opvartning. (Helsetilsynet 2004)

\subsubsection{Tiltaleformer}

Det siste vi skal se på i denne analysen av brevene til Anna, er tiltaleformer. For om hun ikke behersket stilen med de lange setningene med mange innskudd, og om hun var mer direkte i sin formidling av budskapet enn det som var vanlig i hennes samtid, så behersket hun reglene for tiltale. Hun bruker aldri formen $d u$ til Arne. Det å bytte ut 2. person entall med 3. person entall i tiltale er noe hun behersker så godt at det kan være grunn til å tro at dette var noe hun hadde som del av sin muntlige 
kommunikasjon. Vi kjenner til fra andre kilder at omskrivning med 3. person entall var vanlig på 1700-tallet $\mathrm{i}$ alle de skandinaviske landene, $\mathrm{i}$ konkurranse med 2. person flertall $(I)$, f $\varnothing \mathrm{r} 3$. person flertall $(D e)$ ble dominerende i Norge (Knudsen 1949; Nesse 2019).

Det vanligste i disse brevene er at Anna tiltaler Arne med 3. person entall, altså han, men hun bruker også tittel, enten den sivile franske Monsieur, som var det vanligste på denne tiden, eller yrkestitlene Assessor og Professor. Det som på den tiden var en relativt ny germanisme i dansk og norsk, nemlig $D e$, er også i bruk, men er på langt nær så vanlig som han.

\begin{tabular}{|l|l|l|}
\hline Beskrivelse & Form & Antall belegg \\
\hline $\begin{array}{l}\text { 3. person entall, } \\
\text { subjektsform }\end{array}$ & hand & 29 \\
\hline 3. person entall, objektsform & hannem & 1 \\
\hline $\begin{array}{l}\text { 3. person entall, } \\
\text { possessivform }\end{array}$ & hans & 17 \\
\hline $\begin{array}{l}\text { 2. person flertall, } \\
\text { subjektsform }\end{array}$ & I & 2 \\
\hline $\begin{array}{l}\text { 2. person flertall, } \\
\text { objektsform }\end{array}$ & eder & 1 \\
\hline $\begin{array}{l}\text { 3. person flertall, } \\
\text { objektsform }\end{array}$ & dem & 2 \\
\hline $\begin{array}{l}\text { 3. person flertall, } \\
\text { possessivform }\end{array}$ & deris & 9 \\
\hline Sivil tittel & Monsieur & 11 \\
\hline \multirow{2}{*}{ Yrkestittel } & Assessor & 7 \\
\cline { 2 - 3 } & Professor & 1 \\
\hline \multirow{2}{*}{ Etisk tittel } & Hans veledelhed & 10 \\
\cline { 2 - 3 } & deris veledelhed & 4 \\
\cline { 2 - 3 } & hans velbyrdighed & 1 \\
\hline
\end{tabular}

Tabell 5: Samtlige forekomster av tiltale i Annas brev

Alle eksemplene i tabell 5 kunne i moderne norsk uttrykkes ved hjelp av $d u$ eller deg. Hvor stor variasjonen i tiltaleformer var i Annas talemål, vet vi ikke. Ut fra tidens skjønnlitteratur kan en få inntrykk av at ulike typer tiltaleformer var vanligere også i dialektene enn tilfellet er i dag, men dette feltet er ikke godt nok utforsket. 


\section{Oppsummering}

Innledningsvis ble det påstått at en analyse av en vanlig kvinnes brev fra begynnelsen av 1700-tallet kan lære oss noe om norsk språkhistorie. I og med at det ofte fokuseres på at skriftspråket lå langt fra talemålet og derfor var krevende å lære, er det viktig å ta ett og annet dypdykk i språket til en skriver som fremviser stor, intraindividuell variasjon. Variasjonen dekkes i noen grad av vanlig variasjon i samtiden, slik vi finner den belagt i ulike ordbøker som dekker den tidens språklige kilder. Men mye av variasjonen må kunne sies å være hennes egen, og er trolig resultat av lite trening som brevskriver.

Vi har særlig fokusert på rettskrivningen, med noen korte tillegg av syntaktiske særtrekk og interessante trekk ved ordforrådet. Det kan være fornuftig å si at Anna fremstår som en skriver som har lært ganske mye om hva det er å skrive generelt og hvordan man skriver dansk spesielt, og at hun effektivt bruker dette redskapet i en kritisk periode i livet. Mye av det hun ikke får til, kan forklares, ikke først og fremst ved å peke spesifikt på Annas dialekt eller forskjellen mellom dansk og norsk, men ved å peke på hva som er utfordrende når tanker formulert i talemålet skal overføres til skrift.

Særlig har det å få med alle de bokstavene skriftspråket fordret, vært vanskelig å få til. Lange ord ser ut til å få vokalbortfall hyppigere enn korte ord, og konsonantbortfall skjer oftest i konsonantforbindelser. Selv om Anna har et gunstig, dialektalt utgangspunkt for å følge skriftspråkets sedvane med hensyn til fordeling av $p, t, k$ og $b, d, g$, ser vi at hun, som vår tids begynnerskrivere, bytter om på disse bokstavene i det som er kalt parvis plosiverstatning. Hyperkorrekt innsetting av bokstaver som ikke skal være der, som $b$ foran $v$ i ord som ved, er også kjent fra senere tiders skriftlige materiale fra unge eller utrente skrivere.

Metoden som er brukt, inspirert av arbeid med barns skrivning, sammen med en språkhistorisk og dialektologisk vinkling, har vist seg effektiv for å $\varnothing$ ke forståelsen av en skrivers språklige praksis. Hvorvidt en også kan bruke slike metoder for å analysere skriftspråket til mer vante skrivere, gjenstår å unders $\varnothing$ ke. Det er ikke gitt at det vil gi like mye, men det som er klart, er at metoder fra andre vitenskapsdisipliner kan berike språkhistorien, særlig når det gjelder konkrete analyser av skriftspråkskorpus fra den perioden i norsk språkhistorie som det hittil har vært sett på som aller mest problematisk å arbeide med. 


\section{Data}

Brev skrevet med Anna Tormods egen hånd til islendingen Arne Magnusson i København. Datert 15.05.1714, 22.01.1715, 28.11.2015, 14.10.1717, 20.06.1718, 04.08.1719, 30.09.1719, 03.02.1720, 07.08.1720, 11.09.1720, 11.10.1720, 04.12.1722

Utgitt av Kålund 1916

\section{Litteratur}

Blöndal, Sigfús. 1919. Kristian Kålund. 1844-1919. Nordisk tidskrift för bok-och biblioteksväsen, Årgang VI, Stockholm: 202-206. Hentet fra http://heimskringla.no/wiki/Kristian_K\%C3\%A5lund_(Sigfus_Bl $\% \mathrm{C}_{3} \%$ B6ndal)

Den departementale rettskrivningskomite. 1918. Den nye rettskrivning. I Riksmål. II Landsmål. Kristiania: Det mallingske bogtrykkeri.

Elsness, Turid Fosby. 2002. Vi skriver. Stavestrategier hos barn i alderen 7-8 år. Oslo: Unipub forlag.

Elspaß, Stephan. 2015. Private letters as a source for an alternative history of Late Modern German. I: Letter Writing and Language Change (Studies in English Language Series), red. Anita Auer, Daniel Schreier \& Richard J. Watts, 35-52. Cambridge: Cambridge University Press.

Fet, Jostein. 1995. Lesande bønder. Litterer kultur i norske allmugesamfunn før 1840. Oslo: Universitetsforlaget.

- 2005. Skrivande bønder. Skriftkultur på Nord-Vestlandet 1600-1850. Oslo: Det norske samlaget.

García, Ofelia \& Li Wei. 2013. Translanguaging: Language, Bilingualism and Education. Basingstoke: Palgrave Macmillan.

Hannaas, Torleiv (utg.). 1923. Professor Knud Leems Norske Maalsamlingar fraa 1740-aari. Kristiania: Jacob Dybwad.

Hagland, Jan Ragnar, Agnete Nesse \& Hildegunn Otnes. 2018. Skriftkunne og språkmedium. I: Norsk språkhistorie II. Praksis, red. Brit Mæhlum, 31-118. Oslo: Novus forlag.

Haraldsrud, Andreas Drolsum. 2012. Det leses med Æ. En komparativ undersøkelse av norsk og dansk danna talemål 1750-1850. Masteroppgave, Universitetet i Oslo. 
Helsetilsynet. 2004. Et tilbakeblikk på første årgang av en tradisjonsrik rapport. Medisinalmeldingen 1804. Rapport fra Helsetilsynet nr. 6.

Haugen, Odd Einar. 2004. Paleografi. I: Handbok i norrøn filologi, red. Odd Einar Haugen, 175-214. Bergen: Fagbokforlaget.

Huus, Andrea Myklebust. 2018. Distribusjonen av te som infinitivsmerke $i$ norsk. En korpusbasert undersøkelse av utbredelsen av te som infinitivsmerke i norsk. Upublisert masteroppgave, Institutt for lingvistiske og nordiske studier, Universitetet i Oslo.

Jacobsen, Henrik Galberg. 2010. Ret og skrift. Officiel dansk retskrivning 1739-2005. Bind 1: Direktiver-Aktører-Normer. Odense: Syddansk Universitetsforlag.

Jakobsen, Alfred. 1952. Norskhet i språkhet hos Petter Dass 1. Tilleggsbok til Håløygminne. Svorkmo: Svorkmo prenteverk.

Kielland, Axel. 1935. Stavanger borgerbog 1436-1850. Stavanger: Dreyers grafiske anstalt.

Knudsen, Trygve. 1949. Pronomener. Oslo: Universitetets studentkontor.

Koch, Peter \& Wulf Oesterreicher. 1985. Sprache der Nähe - Sprache der Distanz. Mündlichkeit im Spannungsfeld von Sprachtheorie und Sprachgeschichte. Romanistisches Jabrbuch 36, 15-43.

Kristoffersen, Gjert \& Arne Torp. 2016. Fonologi. I: Norskspråkhistorie I. Mønster, red. Helge Sandøy, 101-211. Oslo: Novus forlag.

Kålund, Kristian. 1916. Arne Magnusson. Brevveksling med Torfaus (Pormóður Torfason). København/Kristiania: Gyldendal.

Larsen, Amund B. \& Gerhard Stoltz. 1911-1912. Bergens bymål. Kristiania: Aschehoug.

Myrvoll, Klaus Johan. 2011. Skaldedikt som kjelda til etymologi og ljodleg vokster av norske namn. I: Etymologiens plass $i$ navneforskningen. Rapport fra NORNAs 39. symposium i Halden 11.-13. mai 2010, red. Ole-Jørgen Johannessen \& Tom Schmidt, 105-118. Uppsala: NORNA-förlaget.

Mørck, Endre. 2011. Leddstillinga imellomnorske heilsetninger. Funksjonsog feltanalyse og materialpresentasjon. Oslo: Novus forlag.

- 2018. Seinmellomalderen (1350-1536). I: Norsk språkhistorie IV. Tidslinjer, red. Agnete Nesse, 293-356. Oslo: Novus forlag.

Nesse, Agnete. 2002. Språkkontakt mellom norskog tysk i hansatidens Bergen. Oslo: Novus forlag. 
—. 2011. 'Norskheter i språket hos...' - Et eksempel på minimalistisk språkhistorieskriving? I: Norsk språkhistorie i eldre nynorsk tid (15251814). Minneskrift for Kjartan Ottosson, red. Helge Sandøy \& Ernst Håkon Jahr, 32-47. Oslo: Novus forlag.

- 2012. Editorial Practices and Language Choice: 'Low German Language Monuments' in Norway. I: Language and History, Linguistics and Historiography. Interdisciplinary Approaches, red. Nils Langer, Steffan Davies \& Wim Vandenbussche, 111-126. Oxford: Peter Lang.

- 2013. Innføring i norsk språkhistorie. Oslo: Cappelen Damm Akademisk.

- 2017. Language choice in forming an identity: linguistic innovations by German traders in Bergen. I: Merchants of innovation. The language of traders, red. Esther-Miriam Wagner, Bettina Beinhoff \& Ben Outhwaite, 158-178. Boston/Berlin: Walter de Gruyter.

- 2019. From everyday speech to literary style: The decline of the distant address $D e$ in Norwegian during the twentieth century. I: Journal of Historical Sociolinguistics, 5/1: https://www.degruyter.com/ view/journals/jhsl/5/1/article-20170027.xml

Nesse, Agnete \& Arne Torp. 2018. Dansketiden (1536-1814). I: Norsk språkhistorie IV. Tidslinjer, red. Agnete Nesse, 357-424. Oslo: Novus forlag.

Nygård, Rolf R. 1945. Fra dansk-norsk til norsk riksmål. Rettskrivningsstrevet i bokmål inntil 1907. Oslo: Tanum.

Ottosson, Kjartan. 1997. Purisme på islandsk. I: Purisme på norsk? Norsk språkråds skrifter nr. 4, red. Dag F. Simonsen, 31-37. Oslo: Norsk språkråd.

Pettersen, Egil. 1957. Norskhet i språket hos Dorothe Engelbretsdatter. Bergen: J. D. Beyer.

Ruus, Hanne. 2018. Ældre nydansk ortografi. I: Dansksproghistorie 2. Ord for ord for ord, red. Ebba Hjort, 57-72. Århus: Aarhus Universitetsforlag/Det Danske Sprog- og Litteraturselskab.

Sand øy, Helge. 1996. Talemål. Oslo: Novus.

— 1997. Norvegr eller Noríki? I: Gransking av norsk mål i hundre år etter Ivar Aasen. Rapport frä faghistorisk seminar i Trondheim 3. og 4. oktober 1996, red. Arnold Dalen, 91-104. Trondheim: Tapir forlag.

Schulte, Michael. 2018. Den eldste tiden (-700). I: Norsk språkhistorie IV. Tidslinjer, red. Agnete Nesse, 51-117. Oslo: Novus. 
Skjekkeland, Martin. 1997. Dei norske dialektane. Tradisjonelle særdrag i jamføring med skriftmåla. Kristiansand: Høyskoleforlaget.

Sokoll, Thomas. 2006. Writing for relief: Rhetoric in English pauper letters, 1800-1834. I: Being poor in modern Europe. Historical Perspectives 1800-1940, red. Andreas Gestrich, Stephen King \& Raphael Lutz, 91-112. Oxford: Peter Lang.

Teleman, Ulf. 1979. Språkrätt. Om skolans språknormer och sambällets. Lund: Liber läromedel.

Titlestad, Tormod. 2001. Tormod Torfæus, biografisk portrett. I: Tormod Torfaus - Ei innføring, red. Tormod Titlestad, 9-24. Hafrsfjord: Erling Skjalgssonselskapet.

—. 2009. Tormod Torfæus. https://nbl.snl.no/Tormod_Torfæus

Treiman, Rebecca. 1993. Beginning to spell. A study of first-grade children. Oxford: OUP.

Venås, Kjell. 1990. Den fyrste morgonblånen. Tekster på norsk frå dansketida. Oslo: Novus.

Vikør, Lars S. 2018. Standardspråk og normering. I: Norskspråkhistorie III. Ideologi, red. Tove Bull, 327-419. Oslo: Novus forlag.

Wiggen, Geirr. 1992. Rettskrivings-studier II. Kvalitativ og kvantitativanalyse av rettskrivingsavvik hos østnorske barneskoleelever. Oslo: Universitetet i Oslo.

- 2004. Språkkulturen i Christianias beaumonde. Opplysninger om språk og språkbruk ca. 1790-1830 i Conradine Dunkers brev til Christopher Hansteen. Det kongelige norske videnskabers selskabs skrifter nr. 4, Trondheim: Tapir.

Wiggen, Geirr \& Carsten Elbro. 1994. Språkvitenskapelige beskrivelsesmodeller $i$ studiet av lesing og skriving. Nordiske bidrag. Oslo: Universitetet i Oslo.

\section{Summary}

This article aims to explore the possibilities we have to develop new insights in our understanding of how Norwegian writers acquired the written language during the union between Denmark and Norway, when Danish was used in writing, also in Norway. Methods from the study of children's acquisition of the written language has been applied to letters from the 18th century. The letters in question have, compared to 
other letters written in the same period, much variation and orthographic peculiarities. Such unusual spellings have in historical linguistic research traditionally been classified as either interesting, Norwegian dialect features, or as not interesting mistakes without any importance for historical linguistics. My claim is that also other characteristics in the language of writers of the time have a place in the writing of the history of Norwegian.

Agnete Nesse

Universitetet i Bergen,

Institutt for lingvistiske, litterære og estetiske studier

Postboks 7805

NO-5020 Bergen

Agnete.Nesse@uib.no 